

\section{The Brand Relationship of Cult-Like Following: Developing Scales of Measurement in Apple and Catholic Devotees}

\author{
Yi-Chia Wu \\ Michael S. Minor
}

\section{Introduction}

Religion, a multidimensional influence on human behavior and decision-making, has been underresearched in the marketing discipline, possibly due to the sensitivity of religious topics and difficulties in measuring the impact of so potentially broad a field as "religion." The exploration between individuals and brands through these lenses begins to offer glimpses into the relationship between brands and their devotees.

The global advertising firm Young and Rubicam claimed that "brands are the new religion" and that "people turn to them for meaning" (Rossano 2010). Some argue that religion exists in the cultural context and varies within the shape of cultural influence at a specific point in time. If the ideology expressed by materialism can shape one's judgments, social acceptance, moral issues, and the motivation for pursuing happiness, then that specific ideology can possibly function and impact one's beliefs and further replace the importance and value of one's religion. More extremely, one may take that ideology as one's religion, rather than having an "actual religion" per se. For instance, religion is often used in daily dialogue. In Alexandre O. Philippe's documentary of The People vs. George Lucas (Philippe, Philippe and Kurtz 2011), devoted fans describe George Lucas as "God" because of his ability to create the incredible movie series, Star Wars. The same phenomenon applies to Trekkies participating in Star Trek annual conventions as crucial events in their lives (Nygard 1997).

A cult-like phenomenon emerged among the Apple Macintosh brand community (Belk and Tumbat 2005; Kahney 2004) and was related to certain Apple products. Lam (2001) explores "cultists, fanatics, and zealots" occurring through the lens of Macintosh devotees to follow an "implicit" religion. Both the Apple Macintosh and the Newton brand communities are cultlike denominations of Apple products (Muñiz and Schau 2005).

At this point, it is important to explore some key definitions. According to the Bloomsbury Guide to Human Thought (Cult 1993), cult has two identified meanings in English religious and theological literature: First, an "intense worship of or devotion to a particular saint or deity, who is credited with miracle-working powers" or second, a neo-religious activity, "heterodox sect outside the mainstream churches, often with secret doctrine and worship."

\section{Theoretical Rationale}

The theoretical rationale of this current study lies in understanding how devotees view their beloved brand to analogize those views as a form of a religious belief. The idea of forming a cult-like following of brands and communities was initiated into marketing strategy during the 1980s (Koay and Hernandez Eriksson 2006). At the beginning of the 20th century, comparisons and strategic analyses with the name of "cult brands" appeared in the literature (Berry 1992). As Constantin and Stoenescu (2014) explain, there is one main characteristic that cult brands have in common: "brands for which consumers developed such strong feelings need to be inspirational, remarkable, and relatable" (124). The meaning of "relatable" in this context suggests a level where an individual can express feelings of freedom and their allegiance to products or brands. Contributing to a cult-like brand community not only satisfies one's basic needs for belonging (Atkin 2004), but also allows one to express oneself to a platform as an "outlet for personal fulfilment" (Acosta and Asagayam 2010). Cult brands create a strong relationship "with a group cognitively initiated by individuals" (Acosta and Asagayam 2010, 166). Such cult-like communities and their followers rely on tightly-bonded connections and share a sense of "satisfaction, accomplishment, belonging, and enlightenment" (Ragas and Bueno 2002, xxii-xxiii). Constantin and Stoenescu (2014) generalize their observations from the literature, giving examples of several cult brands such as Apple, Oprah Winfrey, Volkswagen Beetle, Harley-Davidson, Star Trek, and others.

Kozinets (2001) analyzes Star Trek fandom, whose devotion goes beyond entertainment. For its followers, Star Trek's imaginative future worlds provide a venue of escape as well as a platform for cognitive sharing (Sirsi, Ward and Reingen 1996) through an actualization of their imagination. One enthusiastic Star Trek fan that Kozinets interviewed in 1995 made the following statement: "Star Trek is a philosophy that almost approaches a religion. That's what it is. It's replacing religion, for a lot of people" (76).

To explain the formation of a cult-like following, Constantin and Stoenescu (2014) generated eight characteristics that cult brands share, which were identified in the books The Power of Cult Branding, written by Ragas and Bueno (2002), and The Culting of Brands: When Customers Become True Believers written by Atkin (2004) and compiled. To wit: 1) the brand enables individual differences in the way that "brand is different, but same enough." (c.f. Constantin and Stoenescu 2014); 2) cult brand leaders are risk takers and determined fighters (Koay and Hernandez Eriksson 2006); 3) cult brands sell lifestyles (Ragas and Bueno 2002) for customers to fulfil their dreams (Constantin and Stoenescu 2014); 4) cult brands not only satisfy a customer's needs but, more importantly, they must listen and integrate their customers' input (Ragas and Bueno 2002) in order to create evangelists among leading fandoms (Constantin and Stoenescu 2014); 5) and thus, supportive communities are formed to create a sense of belonging and remain authentic to create meanings of oneself (Atkin 2004); 6) cult brands are open and 
inclusive (Ragas and Bueno 2002); 7) cult brands embrace personal freedom and rebellion (Ragas and Bueno 2002); and 8) cult brands demonize the other to create justified credibility (Atkin 2004).

The commonly shared characteristics of cult brands do not mean they all have these eight qualities, but several of these qualities may be observed in describing the success of cult brands. Fisk (1989) pointed out that "commodities become icons of worship and rituals of exchanging money for goods become a secular equivalent of holy communion (sic)" (306).

Starting from an individual's viewpoint specifically, Atkin (2004) explores the reasons individuals are attracted to various groups to "find their own," or, in other words, the need to belong. His interviewees from different cult brand communities explain the reason for becoming a cult member by saying they needed to find a community that would allow them to "become themselves." (16) Sometimes, these devotees are traditional religious devotees, such as those who belong to the Mormon Church. Atkin (2004) often uses "devotees" while discussing cult brands, but whether these individuals' devotion reaches the religious level is not discussed or measured in his qualitative interviews with various cult communities such as Mary Kay, Harley-Davidson, Apple, and others.

In 2005, Apple paved its path to large-scale popularity as a mainstream phenomenon different from the non-mainstream experience of the Newton community. Users of the newer Apple products-i.e., the iPhone, iPad, and iPod-are so ubiquitous that a more recent trend has emerged: Apple users defining themselves in contrast to personal computer, or PC, users. Yet, by shifting from a marginalized group to a mainstream group, the mentality of current Apple users already deviates from that of the Newton community. Devotion in both groups continued even as Apple transformed its image from being "cool" and "innovative" to commanding a powerful market dominance (Belk and Tumbat 2005). Incredibly, the zeal of Apple fans drove Apple to astonishing growth: 22,000 weekly visitors in an Apple store, one billion visitors in total, and $\$ 10$ billion in sales by May 19, 2011 (Gallo 2012).

Hirschman (1983) points to three possible reasons that religion and religion-like consumption is under-researched in the marketing field: 1) topics related to religion and consumption are still limited in consumer research (Mokhlis 2009); 2) the exploration of the relationship between consumption and religion is important because they are interactive and reciprocal, which makes interactions difficult to disentangle; and 3) religion not only influences how much we consume but also why we consume (Hirschman 1983). The analogy has been made that consumption is a new religion. Apple is a suitable entity to study because its consumption is oftentimes a process of self-searching for meaning and validating one's existence through creation and possession (Belk 1988).

\section{Research Question}

This study combines one of the oldest human activities, religion, to explore and explain the process of how the growth of Apple can possibly be analogized as religion. This study used Catholicism as the religious group to examine. Catholicism is the largest single religious denomination in the U.S. (Delener 1994; U.S. Census Bureau 2012), but research regarding Catholicism is limited, and more focus should be paid to the study of this group (Delener 1994). According to the American Religious Identification Survey conducted by the U.S. Census Bureau in 2008, 25\% of the surveyed adult population in the U.S. are Catholic (U.S. Census Bureau 2012). Catholicism emphasizes family ties, which is one of the traits of the Apple community, as well as a basic mechanism to form a religion. Therefore, it is reasonable to compare Apple within the context of Catholicism for the purpose of this study.

It was crucial to identify the factors that cause an individual to react in a cult-like way to a specific brand and to determine what furthers the extreme worship mentality. With the curious nature of Apple's emerging cult-like phenomenon, this research attempts to answer the following question: How, if at all, is religious devotion expressed by Apple fans? More specifically, How, and to what degree, is Apple a cult-like religion for some individuals?

One of the purposes of religion is to reduce anxiety and increase a sense of calmness. When a possession has a function similar to religion, the level of anxiety decreases while using and having the possession - in this case an Apple product. This reflects Belk's (1988) having, doing and being as well as the original goal of Jobs when he created Apple products. That is, through the possession of Apple products and creating work by doing, one has left evidence of being, and it is meaningful to him or her that the creation itself is part of their being. Even though one may not be a professional photographer, musician, or video editor, it takes little effort to create professionally displayed work with a few finger clicks with an iPhone, iPod, or Mac.

\section{Seven Dimensions of Religion and Operationalizations}

Previous scales developed in the literature measure religious belief as it influences the decisionmaking process in consumption (Delener 1990, 1994; Hirschman 1983; Mokhlis 2009; Shukor and Jamal 2013; Wilkes, Burnett and Howell 1986). In these studies, three dimensions of religion, "belief, ritual, and experience," are typically measured (Tan 2006; Tan and Vogel 2008).

Since existing scales did not fit precisely the purpose of this study, modifications were made to existing measures (Donahue 1985; Tan and Vogel 2008; Worthington et al. 2003) based on the seven dimensions of religion (Smart 1989). In addition, there is no existing Apple religiosity scale meeting the purpose of this research. These new scales were used to assess the degree of Apple and Catholic devotion. During this research, a Catholic scale was developed based on previous literature, and then an Apple scale was developed to align with the items in the Catholic scale.

Religion impacts consumer behavior in terms of values, decision-making, and judgments (MacInnis and Folkes 2010). When religion is used as a variable to differentiate an individual's behavior instead of a correlated component with religious goods, religion can 
be considered a predictor of consumer behavior (MacInnis and Folkes 2010). There are two important components of religion relevant to this study: 1 ) religious affiliation and 2) religiosity. Religious affiliation generally refers to the major religions of Christianity, Judaism, Islam, Buddhism, and Hinduism. Religiosity indicates the degree of belief.

Smart (1989) proposes seven dimensions of religion in his book, The World's Religions. Each dimension is explained and examples provided; the definitions are provided below. These detailed explanations and examples of the seven dimensions of religion (Smart 1978, 1989, 12-20; Smart 1996) are:

1) Practical/Ritual: This dimension is particularly important with faith in the form of a sacrament. Patterns of behavior are ways to develop spiritual awareness. Scales were derived from Worthington et al. (2003) and Thurstone and Chave (1929).

2) Experiential/Emotional: This dimension contains religious experiences and feelings of being exposed to sacred awe. Scales were derived from Thurstone and Chave (1929) and Allport and Ross (1967).

3) Narrative/ Mythic: The "storytelling" of a religion. The examples include written and oral forms of informal teaching. Scales were derived from Worthington et al. (2003), Thurstone and Chave (1929), Ganzevoort (1998), and Faulkner and De Jong (1966).

4) Doctrinal/ Philosophical: This dimension refers to the aspect of religion expressed in relatively abstract and philosophical terms. Scales were derived from Worthington et al. (2003), Thurstone and Chave (1929), and Allport and Ross (1967)

5) Ethical/Legal: This dimension includes the laws, morals and formal guidelines derived from the system. Scales were derived from Thurstone and Chave (1929) and Allport and Ross (1967).

6) Social/Institutional: The influence and understanding of faith can be observed among a group of people, which is the sociological component of religion. The social identity may be recognized within a small group of people, or it may be in line with the society on a large scale. Scales were derived from Worthington et al. (2003) and Thurstone and Chave (1929).

7) Material: This dimension contains buildings, architecture, arts, images, icons, and instruments of ritual. Scales were derived from Bader, Forese, Johnson, Mencken, and Stark (2005).

These seven dimensions serve as
fundamental concepts for social scientists, neuroscientists, and anthropologists to explore and explain human behaviors. Specifically, social scientists can explore the phenomena of all seven dimensions in descriptive and quantitative measurements in the virtual and physical world.

\section{Method}

A questionnaire was used to test the Apple and Catholic devotees. The purpose of the scale development was to allow participants to convey the meanings of religion and the meanings of Apple individually. The empirical testing related to the seven dimensions of religion enabled further understanding of how Apple and Catholic devotees set priorities among the seven dimensions in their beloved brand and religion.

Pilot Study

The new scales, in the Catholic and Apple context, were developed by the researcher. The initial Catholic and Apple scales were with 51 and 47 items in the pilot study. Participants were asked to answer each question on a scale of 1 to 10 ( 1 being "Strongly Disagree" and 10 being "Strongly Agree"). The pilot study was an online survey distributed through Qualtrics with convenience sampling.

The data collection timeframe for the pilot study was from April 1 to 14, 2014. Participants were asked for their instructor's name and their student ID number in order to earn extra credit for taking the survey. Participants were required to be a Catholic and had to have used an Apple product to fit the criteria of this research. In order to avoid biased answers from the online survey, participants were asked to choose their religious belief if he or she was not a Catholic. Even though a Catholic can be referred to as a Christian, a Christian is not necessary a Catholic. Therefore, the first question asked was, "Are you a Catholic?" If the participant chose the answer, "No," The second question asked was, "What is your religious belief?" The answer options for religious belief included: Christianity, Islam, Buddhism, Judaism, and Others. The available option of "Others" takes into consideration the fact that some are atheists or have a religious belief that is not affiliated with any religious organization listed. Options for an online survey should be inclusive and mutually exclusive. Therefore, the option of "Others" allowed participants to choose if they considered their religious belief not affiliated with the options provided in the online survey. The third question of the survey appeared next: "I have used Apple products before." Participants who chose "No" would not be included in the study and the survey would end after three questions.

There were 161 questionnaires gathered for the pilot study. Among all responses, five (3.1\%) of them had never used Apple products; four (2.4\%) were incomplete (more than $50 \%$ of the questions were missing); 89 (55.2\%) were Catholic; and $63(39.1 \%)$ were nonCatholic. Among the 63 non-Catholics, 47 respondents identified themselves as non-Catholic Christians; two were Buddhist; and 14 were "Others." Eighty-nine questionnaires from university students who were both Catholic and Apple users were selected for the pilot study.

\section{Exploratory Factor Analysis - Pilot Study}

Exploratory Factor Analysis (EFA) and reliability tests were conducted in the pilot study in order for the newly developed items to be parsimonious. The lengthy initial questionnaire, with a total of 98 items before the pilot study, could potentially cause fatigue of survey participants and therefore needed to be reduced.

The data were analyzed through EFA using SPSS 21. Before conducting EFA, Kaiser-Meyer-Olkin (KMO) tests of sampling adequacy and Bartlett tests of 
sphericity were conducted in order to provide statistical evidence that the data were appropriate for proceeding to factor analysis. Before proceeding to EFA, the correlations among items were examined. The threshold of correlation coefficients between each item is above 0.3 (Hair, Black, Babin and Anderson 2013; Tabachnick and Fidell 2012). Next, a measure of sampling adequacy (MSA) was performed. The MSA values were recommended to be at least 0.5 or above (Hair, Black, Babin, Anderson and Tatham 2006).

This study used Principal Components in the EFA analysis. Smart (1998) indicated the correlation between each dimension. The basis of religion as a multidimensional concept (Allport 1954; Glock 1954; King 1967; King and Hunt 1975) was used as a theoretical framework. The researcher used Promax, an oblique rotation, to demonstrate the nature of correlations (Fabrigar, Wegener, MacCallum and Strahan 1999) between each dimension. Items were excluded due to the combination of multiple testing in the following: crossloadings (Hair, Black, Babin and Anderson 2010), low loading if below 0.4 (Bearden, Hardesty and Rose 2010), partial correlations if above 0.7 (Hair et al. 2010), interitem correlations if below 0.2 (Bearden et al. 2010), and corrected item-to-total correlations if below 0.35 (Bearden et al. 2010). Most importantly, the item was removed if it did not load in any one of the generated factors. The Catholic scale generated five factors in the EFA with corresponding items. Each factor was then examined with Cronbach's Alpha, which ranged from 0.858 to 0.95 . A total of 19 items were removed in the Catholic scale in the pilot study. Therefore, 32 items remaining in the Catholic scale.

The Apple scale generated six factors in the EFA with corresponding items. Each factor was conducted using Cronbach's Alpha, which ranged from 0.685 to 0.910 . Apple's Legal factor is slightly lower, but very close to the threshold of 0.7 (Hair et al. 2010). A total of 16 items were removed in the Apple scale in the pilot study. Therefore, there are 31 items in the Apple scale.

\section{Data Collection}

After the pilot study, the remaining 63 items of the scale were distributed through an online survey via Qualtrics. The researcher collected the data through a Qualtrics data collection panel. To increase the representativeness of the data, the survey was distributed in the Northeast, West, Midwest, and South regions of the U.S. Survey participants had to be Catholic and had to use Apple products to qualify for the survey. The Qualtrics team sent the survey link to the subjects' emails and asked their willingness to participate. Question 21, which asked: "To ensure you are reading the questions carefully, please select number two for this statement," was added and used as an attention check question in the middle of the survey to ensure participants were reading each question (Oppenheimer, Meyvis and Davidenko 2009). Responses were excluded if this question was answered incorrectly. After the filtering and demographic questions, participants started with the Catholic scale questions, then the Apple scale questions.
The pool of participants in this study focuses on both Apple and Catholic devotees. General users, but not devotees, of Apple products were recruited but are not targets for this study; the same criterion applies to practitioners of the Catholic faith.

\section{Results}

A total of 708 surveys were collected. Participants were located in the Northeast (23.4\%), West (20.9\%), Midwest (21.9\%), and South (33.7\%). Table 1 demonstrates the demographics of the total samples. This survey was distributed to the four main areas in the U.S. from May 16, 2014 to August 14, 2014.

Table 1: Sample Demographics

\begin{tabular}{|l|c|c|}
\hline Gender & Frequency & Percent \\
\hline Male & 264 & $37.3 \%$ \\
\hline Female & 444 & $62.7 \%$ \\
\hline Average Age & 35.6 & \\
\hline Region & & \\
\hline Midwest & 155 & $21.9 \%$ \\
\hline Northeast & 166 & $23.4 \%$ \\
\hline South & 239 & $33.8 \%$ \\
\hline West & 148 & $20.9 \%$ \\
\hline Household Income & 95 & \\
\hline Less than \$25,000 & 93 & $13.4 \%$ \\
\hline \$25,000-\$34,999 & 105 & $13.2 \%$ \\
\hline \$35,000-\$49,999 & 201 & $28.4 \%$ \\
\hline \$50,000-\$74,999 & 117 & $16.5 \%$ \\
\hline \$75,000-\$99,999 & 96 & $13.6 \%$ \\
\hline More than \$100,000 & & \\
\hline Education Level & 109 & $15.4 \%$ \\
\hline $\begin{array}{l}\text { Graduated high school or } \\
\text { equivalent }\end{array}$ & 183 & $25.8 \%$ \\
\hline Some college, no degree & 103 & $14.5 \%$ \\
\hline Associate degree & 228 & $32.2 \%$ \\
\hline Bachelor's degree & 85 & $12.0 \%$ \\
\hline Post-graduate degree & & \\
\hline
\end{tabular}

There was a total of 65 questions in the main study. Bagozzi and Yi (2012) suggest that the ratio of the number of questions to survey participants should be $1: 10$. This study reached the requirement of this ratio. In order to achieve generalizability, this research included not only student samples, which has the drawback of homogeneity, but also other Catholic and Apple users residing in the four main areas of the United States.

Exploratory Factor Analysis

Exploratory Factor Analysis (EFA) was conducted to extract factors of the online survey based on the items extracted from the pretest. A Promax rotation with Principal Components was performed due to the correlation between dimensions in nature (Fabrigar et al. 1999; Hair et al. 2013). Kaiser-Meyer-Olkin (KMO) tests of sampling adequacy and Bartlett tests of sphericity (Bartlett 1954) were conducted in order to provide statistical evidence that the data were acceptable to proceed toward factor analysis. The KMO measure value is 0.971, which meets the threshold of 0.6 (Pallant 2010) and is above 0.9 , which indicates a great suitability for analysis (Kaiser 1974). A significant test result of Bartlett 
tests of sphericity rejects the null hypothesis that there is no correlation among variables. The Catholic scale produced a significant Bartlett test of sphericity $(p=$ $0.000)$.

In the Catholic scale, total of five items were excluded after conducting an EFA. Item CR14 (I pray every day without the need to go to Mass) was excluded because this item did not load in any one of the generated factors. CE3 (Religion is relevant to my deepest feelings) and CI4 (I have influence in the decisions of my local religious group) were removed due to cross-loading. CR7 (I pray the rosary every day) and CR13 (I pray to Saints) were removed because neither item loaded at all. Cronbach's Alpha for the three new extracted factors was above 0.7 (Hair et al. 2013). All the factor loadings were above the threshold of 0.5 except CE2 (I enjoy working in the activities of my religious affiliation), which had a factor loading of 0.47 .

In the Apple scale, total of six items were excluded after running an EFA. Item AR3 (I do not like Apple, Inc., so I do not care to buy any Apple products) and AR7 (I really worship Apple, Inc.) were removed due to a low inter-item correlation, which was less than the threshold of 0.2 (Bearden et al. 2001). AD3 (The simplicity of Apple products is the source of Apple's growth) and AL2 (I don't think Apple, Inc., is truthful to its customers) were excluded due to cross-loadings after several tests using the Promax rotation. AL1 (Apple does not cheat its customers.) and AN4 (I am totally captivated by the stories about Apple.) were removed because neither item loaded at all.

\section{Confirmatory Factor Analysis}

After running EFA, the Catholic scale generated three factors, whereas the Apple scale generated four factors. The three factors in the Catholic scale involved 17,5 , and 5 items, while the four factors in the Apple scale involved 12, 7, 3, and 3 items separately. Table 2 demonstrates the factor loadings using AMOS 22.0 for each item with all seven factors from the Catholic and Apple scales, along with Cronbach's Alpha, construct reliability, and average variance extract (AVE) to test for convergent validity.
Table 2: Factor Loadings of Catholic and Apple Scales, AVE, CV, and Cronbach's Alpha

\begin{tabular}{|c|c|c|c|c|c|}
\hline & & $\begin{array}{l}\text { Standardized } \\
\text { Factor } \\
\text { Loadings } \\
\end{array}$ & AVE & $\begin{array}{l}\text { Construct } \\
\text { Validity }\end{array}$ & $\begin{array}{c}\text { Cronbach's } \\
\text { Alpha }\end{array}$ \\
\hline \multicolumn{2}{|c|}{ Catholic Religiosity } & & 0.67 & 0.971 & 0.971 \\
\hline CDI & $\begin{array}{l}\text { I spend time trying to grow in } \\
\text { understanding my faith. }\end{array}$ & $0.839 *$ & & & \\
\hline $\mathrm{CD} 3$ & $\begin{array}{l}\text { The Ten Commandments of } \\
\text { The Bible are what I believe in. }\end{array}$ & $0.807^{*}$ & & & \\
\hline $\mathrm{CD} 5$ & $\begin{array}{l}\text { I believe God created the } \\
\text { universe. }\end{array}$ & $0.763 *$ & & & \\
\hline CE4 & $\begin{array}{l}\text { Any spiritual experience could } \\
\text { be considered a sign connecting } \\
\text { with God. }\end{array}$ & $0.688^{*}$ & & & \\
\hline CE5 & $\begin{array}{l}\text { Believing in my religion is } \\
\text { comforting. }\end{array}$ & $0.845^{*}$ & & & \\
\hline CE6 & $\begin{array}{l}\text { My religious belief makes me } \\
\text { feel secure. }\end{array}$ & $0.875^{*}$ & & & \\
\hline CE7 & I have felt the presence of God. & $0.783 *$ & & & \\
\hline CL1 & $\begin{array}{l}\text { Religion is concerned with my } \\
\text { greatest values. }\end{array}$ & $0.907 *$ & & & \\
\hline CL3 & $\begin{array}{l}\text { My religious belief guides my } \\
\text { judgment of right and wrong. }\end{array}$ & $0.860^{*}$ & & & \\
\hline CL4 & $\begin{array}{l}\text { Religion is the foundation for } \\
\text { establishing ethics. }\end{array}$ & $0.839 *$ & & & \\
\hline CL6 & $\begin{array}{l}\text { My religious belief helps me to } \\
\text { make ethical decisions. }\end{array}$ & $0.888 *$ & & & \\
\hline $\mathrm{CN} 2$ & $\begin{array}{l}\text { The story of Jesus Christ } \\
\text { shapes my belief. }\end{array}$ & $0.909 *$ & & & \\
\hline $\mathrm{CN} 3$ & $\begin{array}{l}\text { I think the stories in the Bible } \\
\text { are well documented. }\end{array}$ & $0.824 *$ & & & \\
\hline $\mathrm{CN} 4$ & $\begin{array}{l}\text { I believe in the miracles written } \\
\text { in the Bible. }\end{array}$ & $0.875^{*}$ & & & \\
\hline $\mathrm{CN5}$ & $\begin{array}{l}\text { The Creation Story in the Bible } \\
\text { is a symbolic narrative of how } \\
\text { the world began. }\end{array}$ & $0.584 *$ & & & \\
\hline $\mathrm{CN} 6$ & $\begin{array}{l}\text { The stories in the Bible define } \\
\text { who } \mathrm{I} a \mathrm{~m} \text {. }\end{array}$ & $0.838 *$ & & & \\
\hline CR11 & I pray every day. & $0.717 *$ & & & \\
\hline \multicolumn{2}{|c|}{ Catholic Rituals at Institution } & & 0.68 & 0.912 & 0.912 \\
\hline $\mathrm{Cn}$ & $\begin{array}{l}\text { I make financial contributions } \\
\text { to my religious organization. }\end{array}$ & $0.831^{*}$ & & & \\
\hline $\mathrm{Cl} 2$ & $\begin{array}{l}\text { I enjoy working in the activities } \\
\text { of my religious affiliation. }\end{array}$ & $0.917^{*}$ & & & \\
\hline $\mathrm{Cl} 3$ & $\begin{array}{l}\text { I keep well informed about my } \\
\text { local religious group. }\end{array}$ & $0.917^{*}$ & & & \\
\hline $\mathrm{CR} 2$ & I rarely go to church $\mathrm{RC}$ & $0.674^{*}$ & & & \\
\hline CR10 & I go to Mass every week & $0.750^{*}$ & & & \\
\hline \multicolumn{2}{|c|}{ Catholic Material } & & 0.78 & 0.945 & 0.945 \\
\hline CMI & $\begin{array}{l}\text { I often purchase books about } \\
\text { religion. }\end{array}$ & $0.891^{*}$ & & & \\
\hline $\mathrm{CM} 2$ & $\begin{array}{l}\text { I purchase items from religious } \\
\text { bookstores regularly. }\end{array}$ & $0.919^{*}$ & & & \\
\hline $\mathrm{CM} 3$ & $\begin{array}{l}\text { I watch religious-themed shows } \\
\text { and speeches frequently. }\end{array}$ & $0.904^{*}$ & & & \\
\hline CM4 & $\begin{array}{l}\text { I listen to religious-themed } \\
\text { music daily. }\end{array}$ & $0.853^{*}$ & & & \\
\hline CMS & $\begin{array}{l}\text { I collect religious-themed } \\
\text { items. }\end{array}$ & $0.837^{*}$ & & & \\
\hline \multicolumn{2}{|c|}{ Apple Religiosity } & & 0.63 & 0.957 & 0.957 \\
\hline AEI & $\begin{array}{l}\text { I consider Apple products } \\
\text { gacred. }\end{array}$ & $0.715^{*}$ & & & \\
\hline $\mathrm{AE} 2$ & $\begin{array}{l}\text { My relationship with the Apple } \\
\text { brand is real }\end{array}$ & $0.818^{*}$ & & & \\
\hline AE3 & $\begin{array}{l}\text { If I don't have my Apple } \\
\text { products nearby, I feel a sense } \\
\text { of emptiness. }\end{array}$ & $0.787^{*}$ & & & \\
\hline AE4 & $\begin{array}{l}\text { I think about Apple, Inc, all } \\
\text { the time. }\end{array}$ & $0.783^{*}$ & & & \\
\hline AE5 & $\begin{array}{l}\text { I have a profound relationship } \\
\text { with the Apple brand. }\end{array}$ & $0.869^{*}$ & & & \\
\hline AIl & $\begin{array}{l}\text { Orning Apple products gives } \\
\text { me a sense of belonging. }\end{array}$ & $0.884^{*}$ & & & \\
\hline AI2 & $\begin{array}{l}\text { Seeing people use Apple makes } \\
\text { me feel good. }\end{array}$ & $0.891^{*}$ & & & \\
\hline AI3 & $\begin{array}{l}\text { I like to hang out with people } \\
\text { who tse Apple products. }\end{array}$ & $0.841^{*}$ & & & \\
\hline AI4 4 & $\begin{array}{l}\text { Orning Apple products makes } \\
\text { me feel powerfil. }\end{array}$ & $0.889^{*}$ & & & \\
\hline AI6 & $\begin{array}{l}\text { I am strongly supported by the } \\
\text { Apple (online) community. }\end{array}$ & $0.841^{*}$ & & & \\
\hline \multirow{2}{*}{$\begin{array}{l}\text { AR5 } \\
\text { ARg }\end{array}$} & \multirow{3}{*}{$\begin{array}{l}\text { I only use Apple products. } \\
\text { I offen browse Apple's online } \\
\text { store. } \\
\text { Doctrine on Material }\end{array}$} & $0.612 *$ & & & \\
\hline & & $0.710^{*}$ & & & \\
\hline Apple. & & & 0.65 & 0.927 & 0.925 \\
\hline
\end{tabular}




\begin{tabular}{|c|c|c|c|c|c|}
\hline AD4 & $\begin{array}{l}\text { Apple products are always } \\
\text { ahead of others in innovation. }\end{array}$ & $0.786^{*}$ & & & \\
\hline AD6 & $\begin{array}{l}\text { Apple, Inc., creates products } \\
\text { for creative types. }\end{array}$ & $0.811^{*}$ & & & \\
\hline AE6 & $\begin{array}{l}\text { I love using my Apple } \\
\text { products. }\end{array}$ & $0.801^{*}$ & & & \\
\hline $\mathrm{AM} 2$ & $\begin{array}{l}\text { I am a loyal customer of Apple, } \\
\text { Inc. }\end{array}$ & $0.850^{*}$ & & & \\
\hline $\mathrm{AM} 3$ & $\begin{array}{l}\text { I find Apple products } \\
\text { appealing. }\end{array}$ & $0.872^{*}$ & & & \\
\hline AM4 & $\begin{array}{l}\text { Apple stores attract my } \\
\text { attention. }\end{array}$ & $0.789 *$ & & & \\
\hline AR4 & I like the Apple brand. & $0.710^{*}$ & & & \\
\hline \multicolumn{2}{|c|}{ Apple Narrative } & & 0.72 & 0.887 & 0.887 \\
\hline AN1 & $\begin{array}{l}\text { The stories about Steve Jobs } \\
\text { starting Apple, Inc. tell } \\
\text { everything about the company. }\end{array}$ & $0.836^{*}$ & & & \\
\hline AN3 & $\begin{array}{l}\text { I am affected by the stories } \\
\text { about Steve Jobs. }\end{array}$ & $0.874^{*}$ & & & \\
\hline AN5 & $\begin{array}{l}\text { Stories about Steve Jobs are } \\
\text { inspiring. }\end{array}$ & $0.842^{*}$ & & & \\
\hline \multicolumn{2}{|c|}{ Apple Legal } & & 0.57 & 0.795 & 0.79 \\
\hline $\mathrm{AL3}$ & $\begin{array}{l}\text { The legal issues against Apple, } \\
\text { Inc. do not affect my opinions } \\
\text { about the company. }\end{array}$ & $0.610^{*}$ & & & \\
\hline AL4 & $\begin{array}{l}\text { Any decision Apple, Inc. has } \\
\text { made is legal. }\end{array}$ & $0.741^{*}$ & & & \\
\hline AL5 & $\begin{array}{l}\text { Apple, Inc. sets the standard for } \\
\text { patent protection. }\end{array}$ & $0.889 *$ & & & \\
\hline
\end{tabular}

Jaccard and Wan (1996) suggest using fit indexes to measure the model fit, such as chi-square to the degrees of freedom (CMIN), RMSEA (Root Mean Square Error Approximation), CFI (Comparative Fit Index), and NFI (Normed Fit Index) for multiple examinations for the model fit. These values are presented in Table 3. CMIN is below the suggested threshold of 5 (Wheaton, Muthen, Alwin and Summers 1977) that is considered adequate. RMSEA is below 0.08, which is considered adequate (Hair et al. 2006). CFI and NFI are less than ideal, as they are supposed to be above 0.9 as recommended (Hair et al. 2010). However, considering the Catholic scale, and especially the Apple scale, was developed by this study, lower CFI and NFI are expected.

Table 3: Test Results of Model Fit

\begin{tabular}{lc}
\hline Goodness-of-fit statistics & Model Fit \\
\hline Chi-square/df (CMIN) & 4.787 \\
RMSEA & 0.073 \\
CFI & 0.873 \\
NFI & 0.845 \\
\hline
\end{tabular}

Convergent Validity

Convergent validity indicates the extent to which indicators of constructs share a high degree of variance (Bagozzi, Yi and Phillips 1991). There are three ways to measure convergent validity (Hair et al. 2010): factor loading, average variance extract (AVE), and construct reliability (CR). The threshold for a standardized factor loading should be 0.5 or, ideally, above 0.7 (Hair et al. 2010). AVE is an indicator of convergence and is calculated as a mean variance from the items loading on a specific construct (Hair et al. 2010). All standardized factor loading was above 0.5 and the majority of them were above 0.7. An AVE above 0.5 suggests an adequate convergence. All seven factors fit within this criteria. Cronbach's Alpha evaluates the reliability; this is also an indicator of convergent validity. All the Cronbach's Alphas were above 0.7, which suggests good reliability. Construct reliability, on the other hand, measures internal consistency. All the construct reliability measurements range from 0.795 to 0.971 , suggesting that the items consistently represent the specific latent construct (Hair et al. 2010).

Discriminant Validity. The suggested method for testing for discriminant validity is when the AVE is greater than any of the two factors' squared correlation estimates (Hair et al. 2010). Discriminant validity is achieved if this relationship is valid. This explains more than the correlations between any of the two constructs. Table 4 shows results that indicate the seven constructs have discriminant validity.

Table 4: Discriminant Validity

\begin{tabular}{lccccccc}
\hline Construct & 1 & 2 & 3 & 4 & 5 & 6 & 7 \\
\hline 1. Catholic Religiosity & $\mathbf{0 . 6 7 0}$ & & & & & & \\
2. Catholic Rituals at Institution & 0.666 & $\mathbf{0 . 6 7 8}$ & & & & & \\
3. Catholic Material & 0.436 & 0.629 & $\mathbf{0 . 7 7 7}$ & & & & \\
4. Apple Religiosity & 0.112 & 0.195 & 0.296 & $\mathbf{0 . 6 5 2}$ & & & \\
5. Apple Doctrine on Material & 0.125 & 0.106 & 0.116 & 0.551 & $\mathbf{0 . 6 4 7}$ & & \\
6. Apple Narrative & 0.174 & 0.163 & 0.194 & 0.616 & 0.493 & $\mathbf{0 . 7 2 9}$ & \\
7. Apple Legal & 0.120 & 0.121 & 0.189 & 0.567 & 0.557 & 0.475 & $\mathbf{0 . 5 7 1}$ \\
\hline
\end{tabular}

Values below the diagonal are squared correlations between constructs. Diagonal elements in bold are AVE.

\section{Discussions}

With a theoretical framework, this research provided the foundation to examine an individual's perception of what religion is and whether Apple can be considered similar to a religion.

Factors did not extract as expected in the seven dimensions in both Catholic and Apple scales. After convergent and discriminant validity, there were three constructs generated from the Catholic scale and four constructs generated from the Apple scale. These results were not in line with the seven dimensions of religion that were used for the theoretical framework as expected.

In the Catholic scale, Catholic Religiosity, the first construct, consisted of items from Doctrinal, Emotional, Legal, Narrative and Ritual Dimensions. Catholic Rituals at Institution, the second construct was composed of items from Institutional and Ritual Dimensions. Catholic Material, the third construct included items from the Material Dimension. The possible explanation for these results is that Catholic devotees and indifferents view their devotion to Catholicism in a combination of more than one dimension, rather than a clear separation of each dimension. For example, Smart (1989) indicates that the Ritual and Emotion Dimensions are related. In addition, ritual occurrence to Catholic devotees may be related to the Institutional Dimension, such as going to church on a regular basis.

The Apple scale was developed based on the Catholic scale because there is no existing "Apple scale." It is reasonable to expect that the Apple scale would generate similar constructs in the statement, "Apple is a religion," if Apple devotees evaluated Apple and Catholicism in a similar way. However, the scale development with reliability and validity testing presented different outcomes. For instance, Apple Religiosity, the first Apple construct, included items from the Emotional, Institutional and Ritual Dimensions. Apple Doctrine on Material, the second construct, consisted of items from the Doctrinal, Emotional and Material Dimensions. Apple Narrative, the third 
construct, was composed of items merely from the Narrative Dimension. Apple Legal, the fourth construct, included items from the Legal Dimension only. Interestingly, when all the items $(32=$ Catholic scale; $31=$ Apple scale) were run in EFA, all of the Apple items were negatively correlated with the Catholic items. This correlation remains the same in CFA in that all three Catholic constructs were negatively correlated with the four Apple constructs. This may indicate that Catholic devotees perceive devotion to Apple negatively and vice versa. That is, Catholic indifferents are more likely to have a positive attitude towards Apple.

Antik (2004) explains reasons for the formation of popular cult brand communities. People have the need to belong. When religion or other social means cannot satisfy this need, they look for alternatives. Perhaps Apple is parallel to the way religion reaches its believers and Apple devotees find this alternative to be close enough to fulfil the need to belong, but this study indicates that it does not necessarily have the impact on their minds in the same way a religion does.

\section{Conclusion}

The significance of this research lies in four perspectives, all related to theoretical contributions. In the first perspective, religion is a multidimensional concept that is measured from the perspective of theology (Allport 1954; Glock 1954; King 1967; King and Hunt 1975). In psychology, the research of religion is considered a multilevel, interdisciplinary paradigm (Paloutzian and Park 2013). This research incorporated the institutional aspects proposed by the Smart's seven dimensions of religion to examine the reasons for Apple to develop into such a cult-like phenomenon in comparison to the Catholic context. The results showed that devotees and indifferents practice their religion in different ways when dealing with Apple. Even though there were not seven factors generated in the Catholic and Apple scales separately as expected, the outcomes remain meaningful with self-reporting that helped to identify how individuals classify their devotion to Catholicism and Apple.

The largest factor in the Catholic scale had 17 items. These 17 items are in line with the construct Religious Commitment Inventory, RCI-10, in measuring religiosity (Worthington et al. 2003). CFA analysis in the Catholic scale did not have clearly identified factors falling into the seven dimensions. This may be due to the fact that some participants considered ritual and experiential as one dimension, whereas others considered ritual and material as a separate dimensions, which were defined by intrinsic-extrinsic religiosity (Allport and Ross 1967). Even though the factors did not load as expected, the divided definition of each dimension includes the major shared components of what constitutes a religion.

In the theological literature, there are thirteen common domains to measure religiosity: religious beliefs, spirituality, meaning and values, private practices, attachment, motivating forces, and more (Paloutzian and Park 2013, 65-67), used for their reliability and validity in some studies. One can distinguish differences in the wording of items in the theological literature when compared to the marketing literature. Smart $(1978,1989,1996,1998)$ observed the world's religions, then sought to identify the seven dimensions over twenty years. Those seven dimensions serve as the basis for the theoretical foundation of this study from a rational, observant point of view. However, devotees may consider all religious and spiritual experiences while practicing rituals and producing emotional attachments to their institutions (churches) and the rosary in their daily rituals. Furthermore, from the operational perspective, the construct of "religiosity" allows more statistical testing in terms of reliability and validity (de Vries-Schot, Pieper and van Uden 2012) for a specific religion. A unidimensional definition of religion narrows the complexity and limits the ability to capture dynamic phenomena (Paloutzian and Park 2013).

Apple devotees strongly revealed their feelings toward Apple while taking the survey. Emotional and Institutional Dimensions were extracted in the Apple Religiosity construct as important factors from the survey results. The Apple Doctrine on Material construct includes items from the Doctrinal, Emotional, Material, and Ritual Dimensions. The Legal and Narrative Dimensions in the Apple scale are clearly generated.

For centuries, "Catholics have displayed their faith materially" (McCallion and Bennett-Carpenter 2008, 427). In their research, McCallion and BennettCarpenter indicate that Catholics consider visual displays of faith as a form of evangelization. They tend to present their faith publically by visual, non-verbal, or material means. The material means include the collection of statues, jewelry, and elaborate altars displayed in churches or for domestic collection. The material means are ways for Catholic devotees to express their faith and connect with feeling of transcendence. Catholics are used to the material means in various formats as a symbol to express their faith. Similarly, consumers use material goods to identify themselves as an expression of existence. Therefore, based on this research, the ideal target market for computer manufacturers and marketers would be Catholics who are less religious.

Religion helps one to find identity, discover the meaning of life, and find purpose in one's existence. Religion also functions to bring believers comfort, reduce anxiety, and to contribute to a stable mental state. Brands may, similar to religion, reduce anxiety because of a certain value perceived by users. Whether brands or companies can achieve these same effects needs to be further studied.

\section{References}

Acosta, P. M., and , R. A. J. Asagayam. 2010. Brand Cult: Extending the Notion of Brand Communities. Marketing Management Journal 20: $165-176$.

Allport, G. W. 1954. The Nature of Prejudice. Cambridge, MA: Perseus Books.

Allport, G. W., and , J. M. Ross. 1967. Personal Religious Orientation and Prejudice. Journal of Personality and Social Psychology 5 (4): 432443. 
Atkin, D. 2004. The Culting of Brands: When Customers Become True Believers. New York, NY: Portfolio.

Bader, C. D., P. Forese, B. Johnson, F. C. Mencken, and R. Stark. 2005. Baylor Religion Survey, Wave I. Waco, TX: Baylor Institute for Studies of Religion. Retrieved from http://www.thearda.com/Archive/Files/Descrip tions/BRS2005.asp

Bagozzi, R. P., and Y Yi. 2012. Specification, Evaluation, and Interpretation of Structural Equation Models. Journal of the Academy of Marketing Science 40 (1): 8-34.

Bagozzi, R. P., Y. Yi, and L. W. Phillips. 1991. Assessing construct validity in organizational research. Administrative Science Quarterly 36 (3): 421-458.

Bartlett, M. S. 1954. A Note on the Mulitplying Factors for Various Chi Square Approximations. Journal of the Royal Statistical Society 16 (B): 296-298.

Bearden, W. O., D. M. Hardesty, and R. L. Rose. 2001. Consumer Self-Confidence: Refinements in Conceptualization and Measurement. Journal of Consumer Research 28 (1): 121-134.

Belk, R. W. 1988. Possessions and the Extended Self. Journal of Consumer Research 15 (2): 139168.

Belk, R. W., and G. Tumbat. 2005. The Cult of Macintosh. Consumption, Markets and Culture 8 (3): 205-217.

Berry, J. 1992. The Power of Cult Brands. Adweek's Marketing Week 33 (8): 18-21.

Constantin, V.-D. N., and , R.-D. G. Stoenescu. 2014. The Impact of Origin on Creating a Cult Brand: The Case of Apple. SEA-Practical Application of Science 1 (3): 123-134.

Cult. 1993. In Bloomsbury Guide to Human Thought. Retrieved from https://zeus.tarleton.edu/login?url=https://searc h.credoreference.com/content/entry/bght/cult/0 ?institutionId $=5155$

de Vries-Schot, M. R., J. Z. T. Pieper, and M. H. F. van Uden. 2012. Mature Religiosity Scale: Validity of a New Questionnaire. European Journal of Mental Health 7 (1): 57-71.

Delener, N. 1990. The Effects of Religious Factors on Perceived Risk in Durable Goods Purchase Decisions. Journal of Consumer Marketing 7 (3): 27-38.
Delener, N. 1994. Religious Contrasts in Consumer Decision Behaviour Patterns: Their Dimensions and Marketing Implications. European Journal of Marketing 28 (5): 36-53.

Donahue, M. J. 1985. Intrinsic and Extrinsic Religiousness: The Empirical Research. Journal for the Scientific Study of Religion 24 (4): 418-423.

Fabrigar, L. R., D. T. Wegener, R. C. MacCallum, and E. J. Strahan. 1999. Evaluating the Use of Exploratory Factor Analysis in Psychological Research. Psychological Methods 4 (3): 272299.

Faulkner, J. F., and G. F. De Jong. 1966. Religiosity In 5D: An Empirical Analysis. Social Forces 45 (2): $246-254$.

Fisk, J. 1989. Shopping for Pleasure: Malls, Power, and Resistance. In J. B. Schor and D. B. Holt (Eds.), The Consumer Society Reader. New York, NY: The New Press.

Gallo, C. 2012. The Apple Experience: Secrets to Building Insanely Great Customer Loyalty. New York, NY: McGraw-Hill Education.

Ganzevoort, R. R. 1998. Religious Coping Reconsidered. Part One: An Integrated Approach. Journal of Psychology and Theology 26 (3): 260-275.

Glock, C. Y. 1954. Toward a Typology of Religious Orientation. New York: Bureau of Applied Social Research, Columbia University.

Hair, J. F., , W. C. Black, B. J. Babin, and R. E. Anderson. 2010. Multivariate Data Analysis. Upper Saddle River, NJ: Prentice-Hall. ---2013. Multivariate Data Analysis. Edinburgh Gate, Essex: Pearson Education, Limited.

Hair, J. F., W. C. Black, B. J. Babin, R. E. Anderson, and R. L. Tatham. 2006. Multivariate Data Analysis. Upper Saddle River, NJ: Pearson Prentice Hall.

Hirschman, E. C. 1983. Religious Affiliation and Consumption Processes: An Initial Paradigm. Research in Marketing 6: 131-170.

Jaccard, J., and C. K. Wan. 1996. LISREL Approaches to Interaction Effects in Multiple Regression. Thousand Oaks, CA: Sage Publications.

Kahney, L. 2004. The Cult of Mac. San Francisco, CA: No Starch Press.

Kaiser, H. F. 1974. An Index of Factorial Simplicity. Psychometrika 39 (1): 31-36. 
King, M. B. 1967. Measuring the Religious Variable: Nine Proposed Dimensions. Journal for the Scientific Study of Religion 6: 173-190.

King, M. B., and R. A. Hunt. 1975. Measuring the Religious Variable: National Replication. Journal for the Scientific Study of Religion 14 (1): 13 .

Koay, L., and I. Hernández Eriksson. 2006. A Pragmatic Approach to Sustaining Cult Brand - Case of Apple. Retrieved from database name Master Thesis International Marketing, Mälardalen International Master Academy, School of Business, Tutor: Charlotta Edlund.

Kozinets, R. V. 2001. Utopian Enterprise: Articulating the Meanings of Star Trek's Culture of Consumption. Journal of Consumer Research 28 (1): 67-88.

Lam, P.-Y. 2001. May the Force of the Operating System be with You: Macintosh Devotion as Implicit Religion. Sociology of Religion 62 (2): 243262.

MacInnis, D. J., and V. S. Folkes. 2010. The Disciplinary Status of Consumer Behavior: A Sociology of Science Perspective on Key Controversies. Journal of Consumer Research 36 (6): 899914.

McCallion, M. J., and B. Bennett-Carpenter. 2008. Displays of Faith: Material/Visual Versus Cognitive/Verbal. Review of Religious Research 49 (4): 427-437.

Mokhlis, S. 2009. Relevancy and Measurement of Religiosity in Consumer Behavior Research. International Business Research 2 (3): 75-84.

Muñiz Jr., A. M., and H. Jensen Schau. 2005. Religiosity in the Abandoned Apple Newton Brand Community. Journal of Consumer Research 31 (4): 737-747.

Nygard, R. 1997. Trekkies [Motion Picture]. United States: NEO Motion Pictures.

Oppenheimer, D. M., T. Meyvis, and N. Davidenko. 2009. Instructional Manipulation Checks: Detecting Satisficing to Increase Statistical Power. Journal of Experimental Social Psychology 45: 867-872.

Pallant, J. 2010. SPSS Survival Manual: A Step by Step Guide to Data Analysis Using SPSS. Australia: Allen and Unwin.

Paloutzian, R. F., and C. L. Park. 2013. Handbook of the Psychology of Religion and Spirituality, Second Edition. New York, NY: Guilford Publications.
Philippe, A. O., V. Philippe, and G. Kurtz. 2011. The People Vs. George Lucas. Santa Monica, CA: Lionsgate.

Ragas, M. W., and B. J. Bueno. 2002. The Power of Cult Branding: How 9 Magnetic Brands Turned Customers into Loyal Followers (and Yours Can, Too!). Roseville, CA: Prima.

Rossano, M. J. 2010. "Sacred Brands: Consumerism as Modern Religion." (accessed April 23, 2013), [available at http://www.huffingtonpost.com/matt-jrossano/sacred-brandsconsumerism_b_789303.html].

Shukor, A. S., and A. Jamal. 2013. Developing Scales for Measuring Religiosity in the Context of Consumer Research. Research in Contemporary Islamic Finance and Wealth Management 13: 69-74.

Sirsi, A. K., J. C. Ward, and P. H. Reingen. 1996. Microcultural Analysis of Variation in Sharing of Causal Reasoning about Behavior. Journal of Consumer Research 22 (March): 345-372.

Smart, N. 1978. The Phenomenon of Religion. London: Mowbrays.

Smart, N. 1989. The World's Religions: Old Traditions and Modern Transformations. New York, NY: Cambridge UP.

Smart, N. 1996. Dimensions of the Sacred: An Anatomy of the World's Beliefs. Berkeley, CA: University of California Press.

Smart, N. 1998. The World's Religions. New York, NY: Cambridge University Press.

Tabachnick, B. G., and L. S. Fidell. 2012. Using Multivariate Statistics. Boston, MA: Pearson Education.

Tan, J. H. W. 2006. Religion and Social Preferences: An Experimental Study. Economics Letters 90 (1): $60-67$.

Tan, J. H. W., and C. Vogel. 2008. Religion and Trust: An Experimental Study. Journal of Economic Psychology 29 (6): 832-848.

Thurstone, L. L., and E. L. Chave. 1929. The Measurement of Attitudes: A Psychophysical Method and Some Experiments with a Scale for Measuring Attitude toward the Church. Chicago, IL: University of Chicago Press.

U.S. Census Bureau. 2012. Statistical Abstract of the United States: 2012 (131st Edition). Retrieved from

https://www2.census.gov/library/publications/2 011/compendia/statab/131ed/tables/pop.pdf 
Wheaton, B., B. Muthen, D. F. Alwin, and G. F. Summers. 1977. Assessing Reliability and Stability in Panel Models. Sociological Methodology 8 (1): 84-136.

Wilkes, R. E., J. J. Burnett, and R. D. Howell. 1986. On the Meaning and Measurement of Religiosity in Consumer Research. Journal of the Academy of Marketing Science 14 (1): 47.

Worthington Jr., E. L., N. G. Wade, T. L. Hight, J. S. Ripley, M. E. McCullough, J. W. Berry, and L. O'Connor. 2003. The Religious Commitment Inventory-10: Development, Refinement, and Validation of a Brief Scale for Research and Counseling. Journal of Counseling Psychology 50 (1): 84-96. 